\title{
Disease-causing gene-flanking genomic rearrangements in HNPCC patients
}

\author{
Monika Morak ${ }^{1,2}$, Trisari Massdorf ${ }^{1}$, Melanie Locher ${ }^{2}$, Elke Holinski-Feder ${ }^{1,2^{*}}$ \\ From 14th Annual Meeting of the Collaborative Group of the Americas on Inherited Colorectal Cancer \\ Dallas, TX, USA. 12-13 October 2010
}

\section{Background}

The molecular diagnosis of hereditary non-polyposis colorectal cancer (HNPCC) or Lynch-Syndrome is the detection of a pathogenic germline mutation in one of the DNA mismatch repair (MMR) genes. However, in $\sim 10-20 \%$ of cases suspected of Lynch-syndrome no disease-causing mechanism can be detected. Genomic rearrangements such as gene-flanking deletions, inversions, duplications, or translocations might affect MMR genes - but are difficult to detect. We report here two different disease-causing rearrangement mechanisms in HNPCC patients flanking the gene in question.

\section{Material and methods}

37 patients with colorectal tumours lacking MMR protein staining were included if gene sequencing and deletion screening did not detect MMR germline mutations. The genomic situation was analyzed by oligo array, MLPA kits (P003, P248, P072) and abnormalities were investigated by Long-Range PCRs and sequencing. Additionally, cDNA analyses were performed.

\section{Results}

In one patients with loss of $M L H 1$ oligo array analyses detected a deletion in LRRFIP2 exon 20-15, a gene located downstream of $M L H 1$ with antisense-orientation. The deletion was verified by MLPA in LRRFIP2 exon 26, $M L H 1$ exon 1-19 and it's termination codon were unaffected. The deletion starting after $M L H 1$ affecting LRRFIP2 could per se not explain the pathogenicity on the $M L H 1$ gene. In cDNA analyses the coding SNP c.655A>G in $M L H 1$ exon 8 showed biallelic expression amplifying exons 3-9, 6-9, 3-11, 7/8-14, but monoallelic c.655G in fragments from exon 1-19, 7/8$16,7 / 8-18$. Suspecting a paracentric inversion we identified two fusion transcripts: $M L H 1$ exon $1-15$ and LRRFIP2 exon 29 in frame, and LRRFIP2 exon 1-3 fused with $M L H 1$ exon 16-19 in frame. The inversion breakpoints in MLH1 intron 15 and LRRFIP2 intron 3 with deletion of exons 4-28 were verified in genomic DNA.

A duplication of the complete $M L H 1$ promoter region and exon 1-19 was found in a patient, his unaffected sister and affected mother. Duplication carriers all showed MLH1 promoter hypermethylation of $8-18 \%$ to $14-25 \%$ in DNA from blood, hair follice, colonic and buccal mucosa. We hypothesize that mosaic methylation is a consequence of transcriptional silencing. As cDNA analyses were not informative so far, quantification of MLH1 expression could not be investigated and no fusion transcripts detected.

\section{Conclusion}

We report disease-causing rearrangements in HNPCC patients: one appeared as a deletion of the LRRFIP2 gene downstream of $M L H 1$ but revealed as a paracentric inversion between the two genes creating two new stable fusion transcripts, the other one is a silencing mechanism accompanied with promoter methylation caused by a duplication of the complete $M L H 1$ gene and flanking region leaving the $M L H 1$ gene and promotor per se intact. In the remaining unsolved HNPCCsuspected patients we expect further mechanisms in the genome to decommission the respective gene which might be detectable by new technologies.

${ }^{1}$ University Hospital of the Ludwig-Maximilians-University, Campus

Innenstadt, Munich, 80336, Germany

Full list of author information is available at the end of the article

(c) 2011 Morak et al; licensee BioMed Central Ltd. This is an open access article distributed under the terms of the Creative Commons Attribution License (http://creativecommons.org/licenses/by/2.0), which permits unrestricted use, distribution, and reproduction in any medium, provided the original work is properly cited. 


\section{Author details}

'University Hospital of the Ludwig-Maximilians-University, Campus

Innenstadt, Munich, 80336, Germany. ${ }^{2}$ MGZ - Center of Medical Genetics,

Munich, 80335, Germany.

Published: 10 March 2011

doi:10.1186/1897-4287-9-S1-P28

Cite this article as: Morak et al:: Disease-causing gene-flanking genomic rearrangements in HNPCC patients. Hereditary Cancer in Clinical Practice 2011 9(Suppl 1):P28.

Submit your next manuscript to BioMed Central and take full advantage of:

- Convenient online submission

- Thorough peer review

- No space constraints or color figure charges

- Immediate publication on acceptance

- Inclusion in PubMed, CAS, Scopus and Google Scholar

- Research which is freely available for redistribution

Submit your manuscript at www.biomedcentral.com/submit
Ciomed Central 